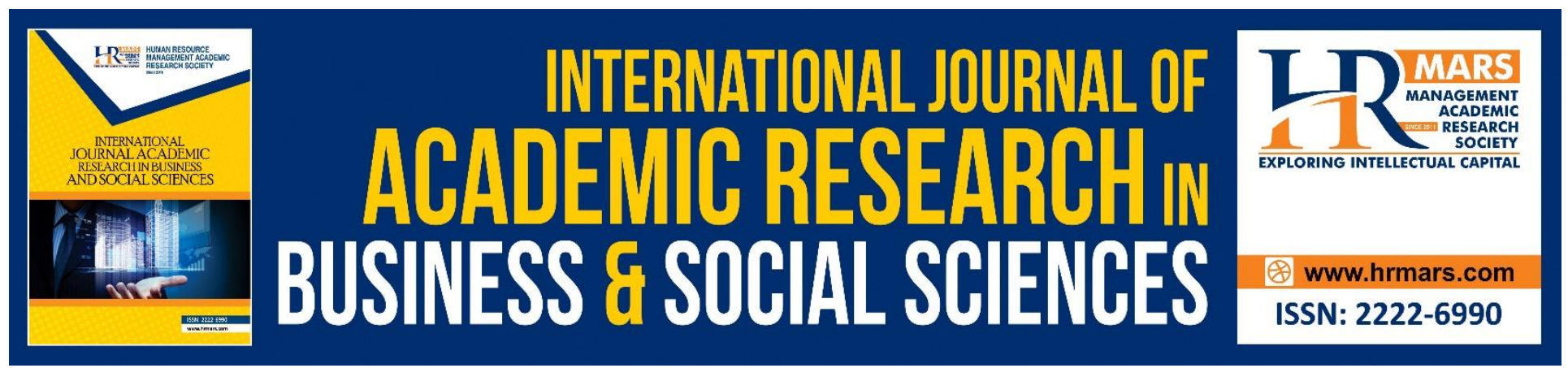

\title{
Is Malaysia Defense Industry Geared towards Self Reliance Capability? A Conceptual Analysis
}

\section{Mohd Nor Yahaya}

To Link this Article: http://dx.doi.org/10.6007/IJARBSS/v9-i1/5371

DOI: $10.6007 /$ IJARBSS/v9-i1/5371

Received: 27 Dec 2018, Revised: 16 Jan 2019, Accepted: 29 Jan 2019

Published Online: 02 Feb 2019

In-Text Citation: (Yahaya, 2019)

To Cite this Article: Yahaya, M. N. (2019). Is Malaysia Defense Industry Geared towards Self Reliance Capability? A Conceptual Analysis. International Journal of Academic Research Business and Social Sciences, 9(2),963968.

\section{Copyright: (C) 2019 The Author(s)}

Published by Human Resource Management Academic Research Society (www.hrmars.com)

This article is published under the Creative Commons Attribution (CC BY 4.0) license. Anyone may reproduce, distribute, translate and create derivative works of this article (for both commercial and non-commercial purposes), subject to full attribution to the original publication and authors. The full terms of this license may be seen at: http://creativecommons.org/licences/by/4.0/legalcode

\section{Vol. 9, No. 1, 2019, Pg. 963- 968}

Full Terms \& Conditions of access and use can be found at http://hrmars.com/index.php/pages/detail/publication-ethics 


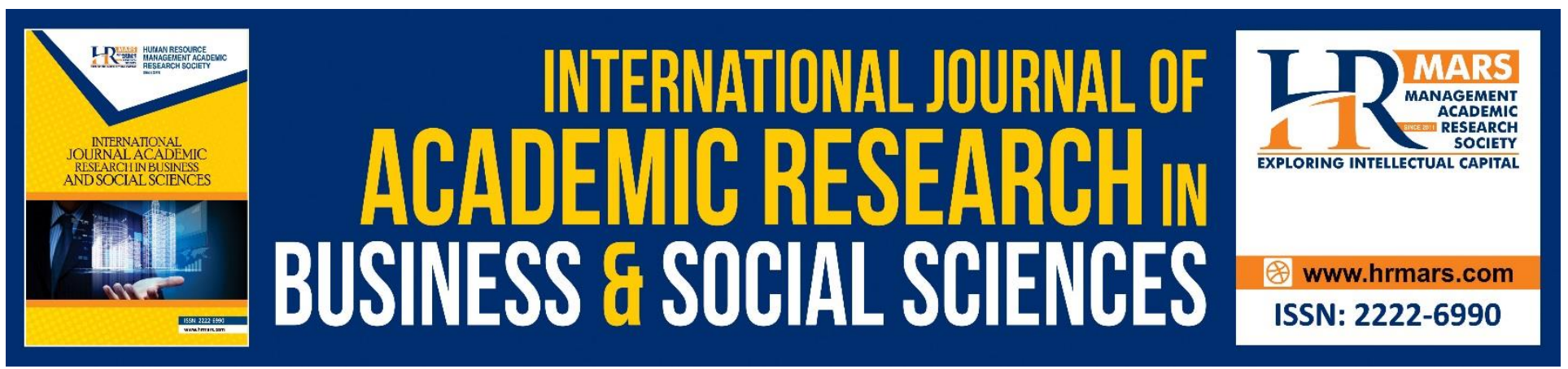

\title{
Is Malaysia Defense Industry Geared towards Self Reliance Capability? A Conceptual Analysis
}

\author{
Mohd Nor Yahaya \\ National Defense University of Malaysia,Malaysia
}

\begin{abstract}
Malaysia defense industry has shown a remarkable achievement in the production, maintenance and supply of defense asset and equipment for the nation. Beginning with the establishment of AIROD in 1976 to support RMAF in aircraft maintenance, the industries has now registered a multi-billion project, with the latest is the production of RM8 billion littoral combat ship (LCS) for the RMN. This paper provides a conceptual analysis on the development of Malaysia selfreliance in the context of defense industry. National self-reliance is defined as the ability of Malaysia to produce, use, maintain and supply major defense asset and equipment without external or foreign support. The approach of the study is qualitative where data are gathered thorough literature study, visit to the defense industrial area and interviewed with the key person in respective industry players for defense. It is found that the nation self-reliance is still in the early stage of development and the way forward is very optimistic if the framework governing the self-reliance is well established. This study provides conceptual analysis on national self-reliance of defense industry in Malaysia.
\end{abstract}

Keywords: Defense Industry, Self-Reliance, Conceptual Analysis

\section{Introduction}

The concept of self reliance in relation to defense industry has drawn a perplexing view from international perspectives especially with regards to its definition (Singh,1998., Subramaniam, 2000., Kwon,2003., Fruhling,2014., Kogila, 2004). The entire process of self-reliance in India should include the indigineous design, development and production of weapons system (singh,1998). Self reliance should be distinguished with self-sufficient (Subrahmaniam,2000). Defense industry in Malaysia to focus self reliance in the capacity of spare and logistics support and maintenance and overhaul without foreign assistance (Kogila,2004). The defense industry blueprint has detailed out the way forward for Malaysia to achive self reliance in the context of low level conflict, capacity to defense any possible aggression with minimum external support in certain industries. Self reliance, in the context of Malaysia, as stated in defense industry blueprint is only to ficus on defense technology Ministry of Defense (2012). At this juncture, no specific definition to what are the expectation and aspiriation of Malaysia in order to achive self reliance. This paper, is however, defined self reliance 
as the capacity and ability to produce, use, maintain and supply major defense asset, equipment and technology without any external or foreign support or assistance.

In the national blueprint, the thrust no 3 has detailed out several key initiatives to drive Malaysia towards achieving its national self-reliance, among others is to enhance and develop in country capability and expertise in defense industry and to encourage partnership with foreign contractors in developing Malaysia product and services for defene and security forces (Ministry of Defense, 2012). Meantime, to encourages technology capability through indigenous development or technology transfer towards increasing local content Kogila (2004). Finally, the objectives is to for the Malaysian to be able to have competencies in design, manufacturing, assembly and marketing at international level for product commercialisation (Ministry of Defense,2012).

\section{Objective}

The objective of this paper is to examine whether Malaysia defense industry has the capability to achieve self-reliance capacity.

\section{Methodology}

This study uses qualitative methodological approaches via literature reviews on on defense industry blueprint and other supporting and related defense industry articles from journals. We also conducted an interview and discussion session with specific, credible and relevant respondents in the industry for confirmation of related issues and visits to the respective industrial area for observation and verification.

\section{Discussion}

Malaysia defense industry has shown a remarkable achievement in the production, maintenance and supply of defense asset and equipment for the nation. Beginning with the establishment of AIROD in 1976 to support RMAF in aircraft maintenance, the industries has now registered a multi-billion project, with the latest is the production of RM8 billion littoral combat ship (LCS) for the RMN. This paper provides a conceptual analysis on the development of Malaysia self-reliance in the context of defense industry. National self-reliance is defined as the ability of Malaysia to produce, use, maintain and supply major defense asset and equipment without external or foreign support. The approach of the study is qualitative where data are gathered thorough literature study, visit to the defense industrial area and interviewed with the key person in respective industry players for defense. It is found that the nation self-reliance is still in the early stage of development and the way forward is very optimistic if the framework governing the self-reliance is well established.

According to sources related to the defense industry, to achieve full fledge self-reliance concept in defense production, use, maintain and supply is long way to go. However, Malaysia has the capacity to produce and export certain defense technology related product such as a radio TCR 5100 in collaboration with Thales, but that does not responded to the self-reliance as expected. A defense industry expert explained that to certain extent Malaysia has capable to handle MRO project locally and this has also evidence limited self-reliance concept. He further stressed that, during a conflict in 
Lahad Datu Sabah, the supply of logistic need are done by the locals. A senior officials defense industry players has mentioned that to achieve full fledge self-reliance is impossible as defense equipment require huge capital investment and furthermore the requirement to have advance technology is very expensive. Defense is interdependence business as our country need to have partner for commercialisation purposes especially for product export. Any defense production need to consider the economic of scale because raw material is limited and it involved high labour cost. A visit to defense industry plant has proved that Malaysia has the capability in shipbuilding and repair, but that does not carries full capability as some of the technology are imported from foreign country. However, the local industries has the advantage by providing training to the locals via transfer of technology. Similar case to the assembly of heavy vehicle where some of the equipment are brought from overseas.

A senior veteran from the armed forces has stated that, Malaysia is facing the deterioration of skill people to work as technologist and engineer as a result of 'brain drain' because of failure to retain skill people due to the rising cost of salary and poor succession planning. This has contributed to the lack of skilled and competent people in the Industry and this shortcomings definitely will have impact on the progression of the defense industry. A blueprint of the defense industry has stated several constraint in the industry, namely lack of technical capabilities and lack of technologist and engineers in weapon system.

\section{Findings}

There is no specific self-reliance definition or a good model of self-reliance to explore in the literature, thus suggest further research in this area. However, for Malaysia to achieve or moving towards achieving full fledge self-reliance, the following framework need to be addressed by the country, that are:

Firstly, an ability to create and develop indigenous product that possess advance technology. This require huge amounts of capital in the form of research and development activities. Country need to invest and produce human resource that have the specialisation in the area of interest and competent as technologist. A proper succession planning and emolument for the competent technologist and other related human capabilities need to be considered by companies in defense industries and nation. Second, the ability to provide modern infrastructure and facilities to support defense production. Third, ability to promote defense product for commercialisation purpose via industry collaboration, partnership and potential users. Fourth and Fifth, the ability to provide funding to explore research and development and Sixth, the ability to design and develop reliable and quality product that are acceptable and competitive in the market. Thus, the study suggests to achieve full fledge national self reliance, the following conceptual model (as shown in Figure 1 below) should be adopted by the government and industry: 


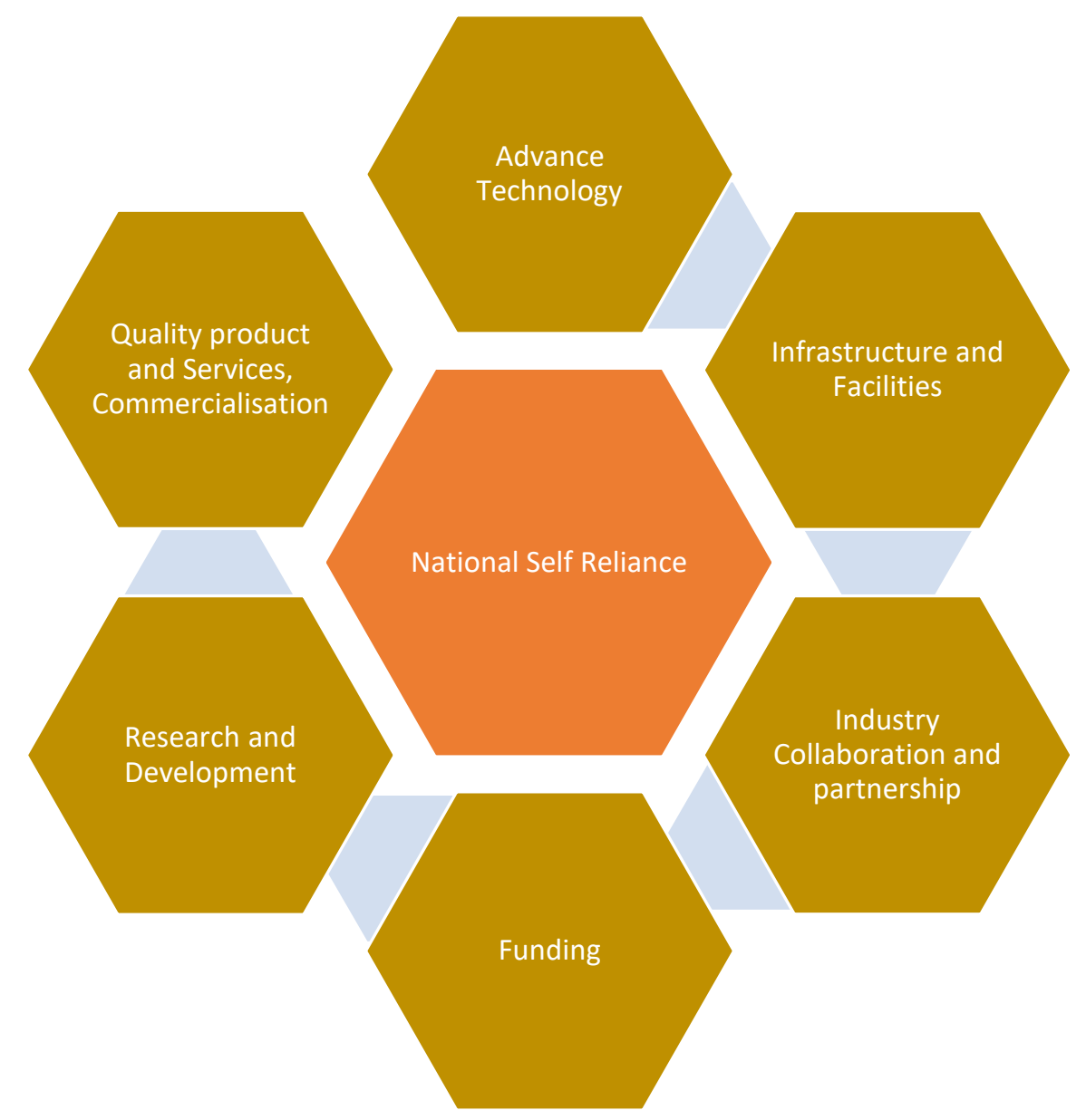

Fig 1. Conceptual Model for National Self Reliance

\section{Conclusion}

Self-reliance is important in defense industry to support self-sufficiency and avoiding over dependency to foreign supplies. Financially and economically, successful self reliance nation in defense industry may help the nation in the form of cost saving in term of reducing balance of payment. In the long run, the country able to build the capacity to become defense producer for both domestic need and international market, achieve economics of scale thus creating employment and income to the country to support economic growth for the country via multiplier effect.

\section{Corresponding Author}

Mohd Nor Yahaya, National Defense University of Malaysia (NDUM),

Malaysia, hasanalbanna@upnm.edu.my, Faculty of Management and Defense Studies, NDUM, Sungai Besi Camp, 57000 Kuala Lumpur, +603-90513400 Ext 7612552 
INTERNATIONAL JOURNAL OF ACADEMIC RESEARCH IN BUSINESS AND SOCIAL SCIENCES

Vol. 9, No. 1, Jan, 2019, E-ISSN: 2222-6990 (C) 2019 HRMARS

\section{References}

Singh, A. (1998). Self-Reliance in Indian Defense. Strategic Analysis. Rutledge, 22(3), 339-346.

Subrahmaniam, K. (2000). Self-Reliant Defense and Indian Industry. Strategic Analysis. Routledge. 24(7), 1221-1234.

Kwon, S. (2003). State building in North Korea: from a 'self - reliant' to a 'military-first' state. Asian Affairs Routledge. 34(3), 286-296.

Fruhling, S. (2014). Australian defense policy and the concept of self-reliance. Australian Journal of International Affairs. Routledge. 68(5), 531-547.

Balakrishnan, K. (2004). Defense Industrialization in Malaysia. Development Challenges and the Revolution in Military Affairs. 4(4).135-155.

Ministry of Defense, Malaysia. National Defense, Enforcement and Security Industry Blueprint (2012). Defense Industry Division.

Agha, A.S. (1999). Pakistan defense industry: An effort towards self-reliance. Defense and Peace Economics, Routledge. 10(4), 347-359.

Ministry of Finance, Malaysia. (2011). Policy and Guidelines on Offset Programs in Government Procurement. 